\title{
THE USE OF COMMUNICATIVE LANGUAGE IN ISLAMIC RELIGIOUS EDUCATION LEARNING
}

\section{PENGGUNAAN BAHASA KOMUNIKATIF DALAM PEMBELAJARAN PENDIDIKAN AGAMA ISLAM}

\author{
Edhy Rustan ${ }^{1}$, Fitriani' ${ }^{2}$ \\ ${ }^{1,2}$ Institut Agama Islam Negeri Palopo \\ email:edhy_rustan@iainpalopo.ac.id \\ email:fitri_ani@yahoo.com
}

\section{Received: 15/07/2020, Accepted: 25/08/2020, Published: 29/08/2020}

\begin{abstract}
Effective learning information that is easily understood by students. So the use of communicative language becomes an important topic in learning without exception Islamic religious education. This article discusses the use of communicative language, influential factors, and communicative language needed in the learning of Islamic religious education. Descriptive qualitative data was collected through observation, interviews, documentation, and recording/video. Sources of research data are Islamic educators and students in SMP Negeri 5 Palopo. Data were analyzed using an interactive analysis model of Miles and Huberman which divided into data collection, data reduction, data presentation and conclusion drawing. The researchers' findings show that the use of communicative language in the teaching of Islamic education is quite good and the factors that influence the use of communicative language are internal and external factors originating from educators, students, and the availability of facilities and infrastructure. Communicative language needed in Islamic religious education learning is communicative language that is easily understood by students, interspersed with the use of local languages, uses appropriate media and teaching aids and takes into account the condition of students while still referring to the communicative competencies that teachers need to have.
\end{abstract}

Keyword: communicative language, learning, Islamic education.

\begin{abstract}
ABSTRAK
Informasi pembelajaran yang efektif yakni mudah dipahami oleh peserta didik. Maka penggunaan bahasa komunikatif menjadi bahasan penting dalam pembelajaran tanpa terkecuali pendidikan agama Islam. Artikel ini membahas tentang penggunaan bahasa komunikatif, faktor yang berpengaruh serta bahasa komunikatif yang diperlukan dalam pembelajaran pendidikan agama Islam. Data kualitatif deskriptif dikumpulkan melalui observasi, wawancara, dokumentasi dan perekaman/video. Sumber data penelitian adalah pendidik Pendidikan Agama Islam dan peserta didik di SMP Negeri 5 Palopo. Data dianalisis menggunakan analysis interactive model Miles dan Hubertman yang membagi dalam kegiatan pengumpulan data, reduksi data, penyajian data dan penarikan kesimpulan. Temuan peneliti menunjukkan penggunaan bahasa komunikatif dalam pembelajaran pendidikan agama Islam cukup baik dan faktor yang berpengaruh dalam penggunaan bahasa komunikatif yaitu faktor internal dan faktor eksternal yang berasal dari pendidik, peserta didik dan ketersediaan sarana dan prasarana. Bahasa komunikatif yang diperlukan dalam pembelajaran pendidikan agama Islam yakni bahasa komunikatif yang mudah dipahami oleh peserta didik, diselingi penggunaan bahasa daerah, menggunakan media dan alat peraga yang sesuai dan memerhatikan kondisi siswa dengan tetap mengacu pada kompetensi komunikatif yang wajib dimiliki guru.
\end{abstract}

Keyword: bahasa komunikatif, pembelajaran, Pendidikan Agama Islam. 


\section{A. PENDAHULUAN}

Kenyataan menunjukkan bahwa manusia dan bahasa merupakan satu kesatuan yang utuh tidak dapat dipisahkan antara satu dengan lainnya. Bahasa sebagai alat untuk berinteraksi dan berkomunikasi manusia sebagai mahluk sosial. Saihu (2019: 419) mengungkapak, bahwa komunikasi dibutuhkan karena sesorang tidak bisa hidup sendiri, membutuhkan orang lain, dan kontak dengan orang lain menggunakan komunikasi. Bahasa digunakan manusia untuk berkomunikasi yakni untuk menyampaikan kehendak, mengetahui informasi dan lain sebagainya. Bahasa memegang peranan penting dalam kehidupan manusia sehari-hari sebagai alat untuk menyatakan pikiran dan perasaan termasuk dalam pendidikan formal untuk mentransfer ilmu pengetahuan kepada peserta didik (Iriantara, 2013).

Pembelajaran sebagai proses komunikasi dilakukan secara sengaja dan terencana, karena memiliki tujuan yang ditetapkan terlebih dahulu. Di mana pada proses pembelajaran tujuan yang ingin dicapai adalah peserta didik dapat memahami serta mengamalkan materi pelajaran yang telah disampaikan oleh pendidik sehingga, pembelajaran dapat berlangsung secara efektif (Sutirman, 2013). Kegiatan pendidikan selalu terkait antara dua komponen penting yaitu, pendidik dan peserta didik (Aminatul, 2015). Suatu pembelajaran dapat tercipta dengan kondusif apabila dalam prosesnya tercipta keselarasan atau keserasian antara kedua komponen yakni pendidik dan peserta didik (Djamarah, 2013).

Seorang pendidik memiliki tugas untuk mengajar atau mentransfer ilmunya. Pendidik dituntut memiliki keterampilan dalam menyampaikan materi sehingga apa yang disampaikan dapat diterima dengan baik dan sesuai maksudnya (Mulyasa, 2013). Kegiatan belajar peserta didik dipengaruhi oleh beberapa faktor salah satunya ialah keterampilan pendidik dalam berkomunikasi.

Komunikasi yang terjadi antara pendidik dan peserta didik sangat diharapkan agar terjalin secara komunikatif, yakni kedua pihak dapat memberikan pengertian yang sama terhadap suatu kata. Sehingga tujuan pembelajaran dapat tercapai sebagaimana firman Allah dalam Q.S. An-Nisaa'/4:63 sebagai berikut:

"Mereka itu adalah orang-orang yang Allah mengetahui apa yang di dalam hati mereka. karena itu berpalinglah kamu dari mereka, dan berilah mereka pelajaran, dan Katakanlah kepada mereka Perkataan yang berbekas pada jiwa mereka (Kementerian Agama RI, 2013). 
Ayat tersebut menjelaskan bahwa pembelajaran yang diberikan oleh pendidik kepada peserta didiknya harus berbekas kepada jiwanya yakni diharapkan agar materi yang disampaikan dapat dimengerti dan dipahami sehingga terjadi perubahan tingkah laku terhadap peserta didik sebagai hasil dari pembelajaran yang telah berlangsung.

Sulistiani (2014) telah melakukan penelitian yang sama dengan judul Penggunaan Bahasa Komunikatif dalam Proses Belajar Mengajar pada Siswa MTs. Lamasi di Kecamatan Lamasi Kabupaten Luwu. Penelitian tersebut menunjukkan bahwa pengaruh penggunaan bahasa komunikatif dalam proses belajar mengajar sangat efektif karena dapat mempermudah peserta didik dalam memahami pelajaran pada setiap bidang yang dipaparkan oleh pendidik, baik berupa lisan maupun tulisan.

Rahmawati (2014) juga melakukan penelitian yang sama dengan judul Urgensi Komunikatif antara Orang Tua dan Anak dalam Proses Perkembangan Prilaku Anak di Desa Padang Katapi Kecamatan Bupon Kabupaten Luwu. Hasil dari penelitian di atas menunjukkan bahwa urgensi komunikatif antara orang tua dan anak dalam perkembangan anak di desa padang katapi kabupaten luwu dengan komunikasi antara orang tua dan anak dapat meningkatkan minat belajarnya dengan beberapa faktor yang mempengaruhi timbulnya minat siswa adalah faktor intern dan ekstern. Faktor intern berupa bakat, perhatian, intelegensi, dan perasaan yang terdapat pada diri individu, sedangkan faktor ekstern seperti faktor keluarga, faktor sekolah dan masyarakat.

Hiyana Lamin (2011) dengan judul Penggunaan Bahasa Komunikatif dalam Proses Belajar Mengajar pada SDN Tondok Alla Jaya di Kecamatan Telluwanua Kota Palopo. Penelitian tersebut, memberikan manfaat/hasil terhadap kemampuan pendidik menggunakan bahasa komunikatif dalam proses pembelajaran adalah sebagai interaksi pendidik antara peserta didik dalam proses pembelajaran yang diterapkan oleh pendidik melalui bahasa yang komunikatif pada SDN Tondok Alla Jaya di Kecamatan Telluwanua Kota Palopo.

Uraian tersebut peneliti dapat mengambil kesimpulan bahwa penelitian yang telah dilakukan sebelumnya dengan yang akan dilakukan oleh peneliti memiliki persamaan dan perbedaan penelitian. Persamaannya yaitu terletak pada penggunaan bahasa komunikatif yang dilakukan pendidik dalam proses 
pembelajaran. Apakah dalam penggunaan bahasa komunikatif tersebut memberikan pengaruh yang efektif dalam pembelajaran atau belum.

Perbedaannya dari penelitian tersebut ialah terdapat pada lokasi sekolah yang diambil sebagai tempat untuk meneliti. Pada penelitian yang pertama peneliti tersebut melakukan penelitiannya di lingkungan keluarga yaitu orang tua, sedangkan peneliti melakukan penelitiannya di lingkungan sekolah yakni dalam proses pembelajaran yang dilakukan oleh guru Pendidikan Agama Islam. Kemudian penelitian yang kedua mengambil lokasi yang berbeda yaitu di SDN Tondok Alla Jaya di Kecamatan Telluwanua Kota Palopo. Sedangkan peneliti mengambil lokasi penelitian di SMP Negeri 5 Palopo. Pembelajaran yang berlangsung di SMP Negeri 5 Palopo sebagaimana hasil pengamatan peneliti maka dapat diketahui bahwa para peserta didik dalam mengikuti pelajar yang sering kali mereka tidak memperhatikan dan kurang memahami materi yang sampaikan kepadanya. Melalui penelitian ini diperoleh penggunaan bahasa komunikatif, faktor yang berpengaruh serta bahasa komunikatif yang diperlukan dalam pembelajaran pendidikan agama Islam di SMP Negeri 5 Palopo.

\section{B. TINJAUAN PUSTAKA}

\section{Bahasa Komunikatif}

Bahasa merupakan sarana dalam berkomunikasi. Hal senada diungkapkan Hairuddin dkk dalam Fahmita (2014) menyatakan bahwa, bahasa merupakan alat komunikasi dan melalui bahasa manusia dapat berkomunikasi. Schramm (Ardianto, 2014) mengatakan bahwa untuk berlangsungnya suatu kegiatan komunikasi, minimal diperlukan tiga komponen yaitu source, message, dan distination atau komunikator, pesan dan komunikan. Ketidakhadiran salah satu aspek tersebut meyebabkan komunikasi tidak dapat berlangsung. Komunikasi yang dilakukan harus ada komunikator sebagai seorang yang menyampaikan pesan kepada orang lain, adapun pesan yang ingin disampaikan sebagai tujuan dari komunikasi dan komunikan seseorang yang menerima pesan dari komunikator sehingga apa yang disampaikan dapat diketahui.

Terjadinya komunikasi efektif antara pendidik dan peserta didik sangat tergantung pada kecakapan seorang pendidik dalam membangun komunikasi saat kegiatan pembelajaran. Sebagai seorang pendidik memiliki tugas utama dalam membangun komunikasi secara efektif (Rahman, 2008). Proses komunikasi 
akan lebih efektif jika dua orang yang berkomunikasi itu memiliki kesamaan seperti: asal daerah, bahasa, kepercayaan, tingkat pendidikan, dan sebagainya (Sa'ud, 2013). Kesulitan dengan adanya perbedaan-perbedaan antara individu yang berkomunikasi itu dapat diatasi jika ada emphaty (empati) yaitu kemampuan seseorang untuk memproyeksikan dirinya (mengandaikan dirinya) sama dengan orang lain.

Metode berkomunikasi guru dan siswa sangat penting diperhatikan karena terkait dengan pemberian arahan dalam pembelajaran. Pendidik dituntut untuk mampu berbahasa dan komunikatif yang efektif untuk digunakan dalam menyampaikan materi pelajaran agar dapat dimengerti. Bahasa komunikatif yang digunakan guru membuat siswa mudah memahami materi yang disampaikan guru (DePorter, Readson \& Nourie, 2013).

Komunikatif adalah bagaimana seseorang mampu berkomunikasi dengan mitra tuturnya sesuai dengan kondisi social yang ada (Yati, 2015). Komunikatif seorang guru dapat dilihat dari beberapa prinsip pendekatan komunikatif (Ibrahim, 2020). Pertama, pemilihan dan pengembangan bahan yang disertai dengan pemberian pengalaman belajar. Kedua, penggunaan media dan alat peraga yang bervariasi sesuai dengan materi pelajaran. Ketiga, bahasa yang digunakan disesuaikan dengan tahapan perkembangan siswa.

Dalam berkomunikasi seseorang memerlukan suatu kompetensi agar mampu menyampaikan dan menafsirkan pesan antarpersonal. Kompetensi tersebut dinamakan kompetensi komunikatif. Kompetensi ini lebih menekankan pada fungsi bahasa daripada menguasai kaidah atau tata bahasa itu sendiri. Menurut Canaled dan Swain, kompetensi komunikatif memiliki empat aspek yakni kompetensi gramatikal (kaidah kebahasaan baik verbal maupun nonverbal), kompetensi sosiolinguistik (pengusaan bahasa dalam konteks sosiokultural), kompetensi wacana (kemampuan mnginterpretasi wacana), dan konpetensi strategis (kemampuan menguasai strategis komunikasi) (Astriani, 2014).

Untuk melihat suatu tuturn komunikatif atau tidak maka dapat ditinjau dari karakteristik yang dimiliki oleh kompetensi komunikatif (Astriani, 2014). Diantaranya bersifat dinamis tergantung antara komunikan dan komunikator, melibatkan bahasa tulisan maupun lisan, bersifat kontektual, berkaitan dengan dikotomi kompetensi dan performansi serta bersifat relative dan tidak absolut. Sedangkan prinsip dalam kompetensi 
komunikatif itu sendiri terdiri atas: pembelajar dapat belajar dengan baik jika memfokuskan pembelajaran terhadap bentuk, strategi dan keterampilan dalam belajar, siswa dilibatkan dalam berkomunikasi, penggunaan bahasa muah dipahami dan sesuai dengan kebutuhan dan minat, serta pembelajar akan belajar dengan aik jika pembelajar merasa seagai individu yng memiliki minat dan kebutuhan. Dengan kata lain siswa akan belajar PAI jika dikaitkan dengan sosiokultural dan diberikan pengalaman langsung akan materi yang disampaikan.

\section{Pendidikan Agama Islam}

Pendidikan agama Islam adalah usaha sadar dan terencana untuk menyiapkan peserta didik dalam meyakini, memahami, menghayati dan mengamalkan ajaran Islam melalui kegiatan bimbingan, pengajaran dan latihan. Depdiknas menyatakan bahwa pendidikan agama Islam adalah upaya sadar dan terencana dalam menyiapkan peserta didik untuk mengenal, memahami, menghayati hingga mengimani, bertaqwa, dan berakhlak mulia dalam mengamalkan ajaran Islam dari sumber utamanya kitab suci al-Qur'an dan al-hadits melalui kegiatan bimbingan, pengajaran, latihan serta pengalaman (Marwiyah, 2015).

Peserta didik merupakan bagian yang terpenting dalam pendidikan Islam mengingat fokus utama pendidikan dalam Islam adalah pembentukan peserta didik menjadi generasi penerus, memberi kesadaran tentang potensi kemanusiaan yang dimiliki dan menggunakan potensi itu sesuai dengan ajaran agama, sehingga pada akhirnya dapat menjadi peserta didik yang memiliki ilmu, iman, dan amal. Dengan demikian dalam mengaplikasikan ilmu yang dimilikinya tidak berorientasi pada materi semata namun sebagai kewajiban manusia dalam rangka pengabdian. Pendidikan Islam mempunyai karakteristik tersendiri, diantaranya adalah penekanan pada pencarian ilmu pengetahuan, penguasaan, dan pengembangan atas dasar ibadah kepada Allah S.W.T.

Pelaksanaan pendidikan agama Islam disekolah/madrasah berdasarkan pada beberapa landasan. Majid Gunawan (2013) mengatakan ada tiga landasan yang mendasari pelaksaan pendidikan agama Islam dilembaga pendidikan dasar dan menengah ketiga landasan tersebut adalah 1) landasan yuridis formal, 2) landasan psikologis, dan 3) landasan religius. Adapun penjelasan ketiga landasan tersebut sebagai berikut:

a. Landasan yuridis maksudnya adalah landasan yang berkaitan dengan dasar dan undang-undang yang berlaku pada suatu negara. 
b. Landasan psikologis ialah landasan yang berhubungan dengan aspek kejiwaan kehidupan bermasyarakat hal ini didasarkan bahwa manusia dalam hidupnya baik sebagai individu maupun sebagai anggota masyrakat, dihadapkan pada hal-hal yang membuat hatinya tidak tenang dan tidak tentram, sehingga memerluka suatu pegangan hidup. Pegangan hidup itu yang dinamakan agama.

c. Landasan religius maksudnya adalah landasan yang bersumber dari ajaran Islam yang meyakini perintah Allah S.W.T. dan merupakan perwujudan ibadah kepadanya.

Menurut Marimba Pendidikan Agama Islam adalah bimbingan jasmani, rohani berdasarkan hukum agama Islam menuju kepada terbentuknya kepribadian utama (Baki, 2014). Pengertian yang lain sering ia mengatakan kepribadian yang memiliki nilai-nilai Islam, memilih dan memutuskan serta berbuat berdasarkan nilai-nilai agama Islam, dan bertanggung jawab sesuai dengan nilai-nilai Islam. Sebagai manusia yang menganut agama Islam maka harus terikat dengan hukum-hukum yang ada dalam agama Islam sehingga setiap perbuatan yang dilakukan dalam kehidupan sesuai dengan tuntunan Islam sehingga dapat tercapai insan yang Islami.

Menurut Somad (2009), pendidikan Islam ialah pendidikan yang bertujuan membentuk individu menjadi mahluk yang bercorak diri, berderajat tinggi menurut ukuran Allah dan isi pendidikannya untuk mewujudkan tujuan itu adalah ajaran Allah S.W.T. Pendidikan dalam Islam memiliki tujuan untuk membentuk individu yang berderajat tinggi sesuai dengan ajaran Allah S.W.T. sebagaimana dalam AlQur'an dan hadits Rasulullah S.A.W.

Komunikasi sebagai sebuah proses interaksi antara subjek dan objek merupakan saran penting yang dapat menjamin kualitas pembelajaran. Proses pembelajaran di sekolah tidak terlepas dari adanya proses komunikasi antara pendidik dan peserta didik. Interaksi antara pendidik dan peserta didik yang bernilai positif yang ditandai oleh kesadaran akan peran dan fungsinya. Untuk mencapai hasil yang optimal dalam pembelajaran perlu adanya prosedur dan langkah-langkah yang sistematis, tentunya dengan memperhatikan komponen yang ada. Komponen tersebut adalah pendidik yang berperan sebagai pembimbing materi pelajaran dengan menggunakan bahasa yang mudah dipahami peserta didik 
(bahasa komunikatif) dalam proses pembelajaran.

Kreativitas seorang pendidik sangat dibutuhkan dalam hal proses pembelajaran terutama dalam menyampaikan materi pelajaran, yaitu bahasa yang merupakan salah satu alat dalam berkomunikasi sangat menentukan peserta didik dapat memahami materi yang disampaikan dengan baik atau tidak. Kebanyakan dari peserta didik yang tidak memahami materi yang disajikan oleh pendidik karena penggunaan bahasa yang tidak komunikatif. Oleh karena itu, pendidik harus mampu menggunakan bahasa yang mudah dipahami oleh peserta didik atau bahasa yang komunikatif.

\section{METODE PENELITIAN}

Penelitian ini merupakan jenis penelitian lapangan deskriptif kualitatif. Fokus menekankan pada aspek pedagogik pengunaan bahasa komunikatif oleh guru dengan mengacu pada kompetensi gramatikal, kompetensi sosiologis, kompetensi wacana, dan kompetensi strategis. Penelitian ini dilaksanakan di SMP Negeri 5 Palopo. Subjek penelitian ini adalah guru Pendidikan Agama Islam yang berjumlah 3 orang dan peserta didik Kelas VIII. Data dikumpulkan melalui observasi guna melihat interaksi langsung penerapan bahasa komunikatif, wawancara untuk mendalami tujuan guru dalam pemilihan diksi serta pola bahasa dan komunikatif bagi siswa, dokumentasi lebih diorientasikan pada manuskrip seperti perencanaan, media, dan bahan ajar sedangkan perekaman dilakukan guna memudahkan transkrip proses komunikasi yang berlangsung dalam pembelajaran. Teknik analisis menggunakan Analysis Interactive model Miles dan Hubertman yang membagi dalam kegiatan pengumpulan data, reduksi data, penyajian data dan penarikan kesimpulan. Teknik pemeriksaan keabsahan data pada penelitian ini menggunakan triangulasi teknik dan triangulasi sumber.

\section{PEMBAHASAN}

\section{Penggunaan Bahasa Komunikatif dalam Pembelajaran}

Berdasarkan penelitian yang telah dilakukan, maka peneliti menemukan, peserta didik dalam pembelajaran dituntut agar dapat mengetahui serta memahami materi pelajaran yang disampaikan oleh pendidik. Hal tersebut dari wawancara DG (27 tahun) yang mengatakan "kita sangat berhati-hati, mereka perlu memahami materi, apalagi tentang fiqih dapat menjadi sesat. Kalau pemahaman salah, kita guru juga ikut berdosa". Berdasar dari hal itu, juga pendidik dituntut menggunakan bahasa yang mudah dipahami atau 
dimengerti peserta didik, dengan kata lain bahasa yang digunakan pendidik pada saat menyampaikan materi harus bahasa yang komunikatif sehingga dapat dipahami. Dengan pemahaman yang baik, peserta didik dapat mengamalkan dalam kehidupan sehari-hari sebagai hasil pengetahuan yang diperoleh dari pembelajaran.

Demikian halnya dengan hasil wawancara dengan SH (40 tahun), juga merupakan guru PAI di SMP Negeri 5 Palopo yang mengatakan bahwa: "Sebagai seorang pendidik guru memiliki tanggung jawab yang sangat besar dalam mengajar dan membimbing. Artinya pendidik harus memberikan pemahaman yang baik kepada peserta didik dalam memberikan pengajaran melalui komunikasi yang komunikatif sehingga dapat dipahami dan diamalkan oleh peserta didik". Lebih lanjut AL (38 tahun) "Dalam proses pembelajaran yang berlangsung di dalam kelas, tujuan utama dalam pembelajaran yakni agar materi atau pesan-pesan keagamaan yang disampaikan kepada peserta didik dapat diterima dengan baik."

Mengacu pada hasil wawancara tersebut dapat diketahui bahwa kesadaran para pendidik akan pentingnya penggunaan bahasa komunikatif dalam pembelajaran dapat dikatakan baik karena mereka menyadari bahwa sebagai seorang pendidik yang memiliki tugas untuk memberikan pelajaran atau mentransfer ilmunya dengan menggunakan bahasa sebagai salah satu alat untuk berkomunikasi dan menyampaikan pesan, maka peran bahasa yang komunikatif sangat diperlukan demi tercapainnya tujuan pembelajaran (Rahman, 2008).

Hasil observasi menunjukkan penyampaian materi pelajaran pendidikan agama Islam, oleh pendidik mengunakan bahasa komunikatif. Hal tersebut dibuktikan dari respons peserta didik yang dapat mengikuti skenatio pembelajaran yang diberikan pendidik. Saat proses pembelajaran berlangsung di dalam kelas, respons peserta didik terlihat ketika diminta untuk menjawab pertanyaan yang diajukan dengan pemahaman yang baik sesuai dengan tujuan pembelajaran.

Upaya yang dilakukan dalam menyampaikan materi pelajaran agama Islam, pendidik terlihat menggunakan berbagai macam cara dengan melakukan kontak mata langsung kepada peserta didik, menyampaikan materi dengan suara yang lantang dan jelas, memberikan penjelasan dengan anggota tubuh misalnya dengan menggunakan gerakan tangan, memberikan contoh yang berkaitan dengan kehidupan sehari-hari peserta didik, 
menunjukkan gambar atau dengan cara menyuruh peserta didik untuk membuka kembali dan membaca buku yang telah dipelajari sebelumnya.

Hasil observasi juga menunjukkan penyampaian materi yang dilakukan oleh pendidik dengan kontak mata yakni pada saat menjelaskan pendidik sesekali menatap mata peserta didik sehingga mereka merasa sangat diperhatikan oleh pendidik. Hasil wawancara dengan siswa "kami senang diperhatikan guru. Kalau dilihat guru jadi fokus" Hal tersebut, menjadikan peserta didik menyimak materi yang disampaikan. Adapun gerakan anggota tubuh seperti gerakan tangan dapat membantu peserta didik untuk lebih fokus menyimak materi.

Ketika memberikan contoh terkait materi pembelajaran, pendidik mencoba untuk mengaitkan dengan kehidupan sehari-hari. Contonya "amalan untuk berbakti kepada kedua orang tua" yakni dengan membantu mereka dalam mengerjakan aktivitas sehari-hari. Hal tersebut dapat memberikan informasi yang mudah dimengerti, karena diorientasikan secara kontekstual peserta didik mengalami dalam kehidupannya seharihari (Ibrahim, 2002). Selain itu, guna memberikan penjelasan yang lebih mendalam, pendidik memberikan informasi oral sambil memperlihatkan gambar yang berkaitan. Dengan penggunaan media gambar membantu siswa memahami materi tanpa harus mengkahayal sehingga materi lebih mudah dipahami (Dahlia, 2019).

Pengunaan sarana dokumentasi yang berupa RPP (rencana pelaksanaan pembelajaran) dalam membantu penyampaian informasi, dibuat sebelum masuk di dalam kelas. Dari hasil triangulasi antara dokumen dengan observasi dapat dikatakan bahwa RPP yang digunakan dalam pembelajaran telah sesuai dengan pengaplikasian di dalam kelas. Misalnya, pada RPP tercantum "indikator menjelaskan materi tentang perilaku tercelah" diajarkan dengan menggunakan sumber yang berupa buku paket yang dibagikan kepada peserta didik. Guna memeroleh informasi, peserta didik mengamati langsung gambar dan menyimak penjelasan yang dipaparkan oleh pendidik.

Data hasil perekaman sebagaimana penjelasan materi yang diungkapkan oleh ibu AL (38 tahun) "sekarang buka halaman 7, sudah liat semua nak? jawab peserta didik iya bu!, hari ini nak kita akan belajar tentang iman kepada kitab-kitab Allah, sebelum ibu menjelaskan tentang kitabkitab Allah ibu mau tanya dulu siapa yang 
tahu ada berapa rukun iman?". Dengan melihat pernyataan tersebut maka dapat disimpulkan bahwa dalam RPP yang telah disusun sesuai dengan penyajian materi disajikan dimana mengikuti langkahlangkah yang tersusun dalam RPP.

Analisis kompetensi komunikatif dengan mengunakan data transkrip rekaman AL (38 tahun) dalam proses pembelajaran dipaparkan berikut:

Ibu guru "Bagaimana kabarnya hari ini : nak?" (sambil memandang peserta didik)

Peserta "baik bu!"

didik :

Ibu guru "Anakku sekalian bahwa sebelum kita mulai pelajaran mari kita bersama-sama membaca surah pendek yaitu Q.S An-Nas, Q.S, al-Falaq, dan Q.S al-Ikhlas". (sambil mendekati peserta didik)

Peserta "iya bu".

didik :

Ibu guru "Hari ini nak kita akan belajar tentang Iman kepada Kitabkitab Allah swt. siapa yang tahu ada berapa rukun iman?" (menatap satu persatu peserta didik dan mengajungkan tangan)

Peserta "Ada enam bu!" (jawab salah didik : satu sebagaian peserta didik).

Lebih lanjut transkrip rekaman $\mathrm{SH}$ (40 tahun), dalam proses pembelajaran:

Ibu guru "sekarang buka halaman 17, : sudah liat semua nak?" (dengan suara lantang)

Peserta "sudah bu!"

didik :

Ibu guru "hari ini kita akan belajar : tentang asma'ul husna?" (berdiri mendekati peserta didik)

\begin{tabular}{|c|c|}
\hline $\begin{array}{l}\text { Peserta } \\
\text { didik : }\end{array}$ & "iye bu". \\
\hline Ibu guru & $\begin{array}{l}\text { "siapa yang tahu apa yang } \\
\text { dimaksud dengan asma'ul } \\
\text { husna". (menatap peserta } \\
\text { didik) }\end{array}$ \\
\hline $\begin{array}{l}\text { Peserta } \\
\text { didik : }\end{array}$ & $\begin{array}{l}\text { "nama-nama Allah } \\
\text { (jawab peserta didik) }\end{array}$ \\
\hline Ibu guru & $\begin{array}{l}\text { "iye betul sekali } n \\
\text { (mengacungkan jempol) }\end{array}$ \\
\hline
\end{tabular}

Dari dua transkrip tersebut, dapat dikatakan kompetensi komunikatif yang berupa kompetensi gramatikal, kompetensi wacana, dan kompetensi strategis. Selain itu juga diperoleh data "iye betul sekali nak." Pengunaan [iye] merupakan bahasa daerah yang berarti "ya" digunakan pengajar agar lebih menyatu dengan pebelajar. Pengorentasian yang dilakukan tersebut merupakan kompetensi sosiolinguistik. Hasil temuan tersebut sesuai dengan pendapat Canale dan Swain (dalam Eva Astriani, 2018) yang membagi kompetensi komunikatif menjadi empat yaitu kompetensi gramatikal, kompetensi sosiologis, kompetensi wacana, dan kompetensi strategis.

\section{Faktor yang Memengaruhi Penggunaan Bahasa Komunikatif}

Hasil penelitian menunjukkan bahwa faktor yang berpengaruh pada penggunaan bahasa komunikatif dalam pembelajaran pendidikan agama Islam yakni faktor intern dan faktor ekstern. Factor intern 
yakni factor yang berasal dari guru sendiri. Berdasarkan hasil wawancara dengan $\mathrm{SH}$ (40 tahun) diketahui bahwa factor dari guru yang berpengaruh terhadap penggunaan bahasa komunikatif adalah penggunaan bahasa yang sulit untuk dipahami ketika menyampaikan materi. Hal senada diungkapkan oleh AL (38 tahun) mengatakan bahwa faktor yang berpengaruh terhadap penggunaan bahasa komunikatif adalah pendidik yang kurang kreatif dalam berkomunikasi secara efektif dengan peserta didik. Karena jika pendidik yang kurang dalam kosa kata akan berpengaruh terhadap hasil belajar peserta didik. Hasil belajar peserta didik akan opimal tergantung dari pendidik, jika pendidik dalam menyampaikan materi sekedar asal-asalan dan terbilang monoton maka peserta didik pun akan kurang memperhatikan pada saat pelajaran berlangsung. Hal ini diperkuat dengan hasil observasi yang menunjukkan bahwa guru tidak mampu menggunakan bahasa komunikatif dalam mengajar pendidikan agama Islam. Guru juga tidak mampu menilai pemahaman siswa akan materi pelajaran.

Sedangkan factor eksternal berasal dari siswa. Berdasarkan hasil wawancara dengan SH (40 tahun) diketahui bahwa peserta didik kurang mampu menangkap materi yang dijelaskan. Dari hasil pengamatan siswa kesulitan memahami materi yang disampaikan guru dan siswa juga Nampak kurang berminat mengikuti pembelajaran dan siswa juga belum. Situasi pembelajaran peserta didik pada waktu pagi dan siang itu sangat berbeda. Perbedaannya terletak pada minat dan kejenuhan peserta didik. Minat belajar peserta didik di waktu pagi masih fokus menerima pelajaran, dan pada waktu menjelang siang sedikit-demi sedikit minat belajar peserta didik mulai menurun. Terlebih di waktu siang konsentrasi belajar peserta didik tidak fokus lagi karena, pada waktu tersebut peserta didik hanya memikirkan untuk bagaimana pelajaran cepat selesai.

Factor eksternal lain yang turut berpengaruh adalah ketersediaan sarana dan prasarana. Ketersediaan sarana dan prasarana tentu sangat menunjang performa guru dalam mengajar. Dari hasil telusur dokumen berupa buku paket atau bahan ajar serta media pembelajaran diketahui bahwa masih kurangnya sarana dan prasarana, sehingga menghambat proses pembelajaran. yang tadinya pendidik bisa menggunakan LCD dalam mengajar untuk membantunya justru media tersebut tidak ada. Sehingga peserta didik dalam memahami materi kurang tepat 
dikarenakan tidak melihat contoh-contoh secara nyata.

Hal ini sejalan dengan yang dikemukakan oleh Tohirin (2011) bahwa faktor internal dan factor eksternal memengaruhi penggunaan bahasa komunikatif dalam pembelajaran. Faktor internal merupakan hal yang ada dalam diri individu yang sedang belajar sedangkan faktor eksternal adalah yang ada di luar individu dimana faktor ini antara satu dengan yang lainnya saling berkaitan. Lebih lanjut Asnawir dan Usman (2002) mengemukakan beberapa hambatan komunikasi yang dapat ditemui dalam proses pembelajaran. Diantaranya, verbalisme guru menerangkan pelajaran hanya melalui kata-kata atau secara lisan, perhatian siswa yang bercabang, kekacauan penafsiran, tidak ada tanggapan, kondisi fisik dan lingkungan mengganggu serta sikap pasif siswa.

Rahman (2008) menambahkan bahwa komunikasi efektif antara pendidik dan peserta didik sangat tergantung pada kecakapan seorang pendidik dalam membangun komunikasi saat kegiatan pembelajaran. Sebagai seorang pendidik memiliki tugas utama dalam membangun komunikasi secara efektif. Oleh karena itu, seorang pendidik harus pandai dalam berbahasa dan komunikatif yang sekiranya efektif untuk digunakan dalam menyampaikan materi pelajaran agar dapat dimengerti. Proses pembelajaran pendidik perlu memahami gaya belajar peserta didik dalam merelevansi gaya mengajar dan gaya belajar memudahkan pendidik dalam meciptakan interaksi belajar yang kondusif. Pembelajaran akan tercipta secara kondusif apabila dalam prosesnya tercipta keselarasan atau keserasian antara kedua komponen yakni pendidik dan peserta didik.

Komunikasi berkaitan dengan interaksi yang dijalani oleh pengajar dan peserta belajar dalam memproses pembelajaran, interaksi menjadi ciri dari keberlangsungan pembelajaran itu sendiri, bahkan dapat dijadikan alat untuk memprediksi perolehan hasil belajar (Sagala, 2013). Hasil belajar yang akan diperoleh oleh peserta didik dipengaruhi oleh komunikasi yang digunakan pendidik dalam menyampaikan informasi atau materi dalam pembelajaran.

\section{Bahasa Komunikatif yang Diperlukan}

Bahasa komunikatif yang diperlukan dalam pembelajaran pendidikan agama Islam dapat diketahui berdasarkan hasil wawancara yang dilakukan kepada AL (38 tahun) mengatakan bahwa "Apabila para guru dalam menjelaskan materi maka diperlukan untuk memperhatikan kondisi 
peserta didik, misalnya kalau kita melihat peserta didik konsentrasinya hilang maka kita selingi dengan bahasa daerah juga dapat digunakan biasanya pada saat menggunakan bahasa daerah mereka langsung paham."

Pernyataan tersebut dapat diketahui bahwa dalam pembelajaran, pendidik mengunakan kontak pandang tidak monoton dan perlu membatasi intensitasnya pada pebelajar tertentu. Hal tersebut perlu dihindari, karena justru akan membuat pebelajar menjadi tidak konsentrasi dan merasa terpantau. Sebagai akibat hal tersebut, pebelajar dapat menjadi cemas dan stress. Ketika siswa berada dalam kondisi stres, norefinephrine memengaruhi amigdala dalam pengambilan keputusan dan motivasi. Selain itu, stress dapat berpengaruh terhadap konsolidasi memori seseorang (Rustan, 2017).

Dari hasil wawancara AL juga diperoleh informasi bahwa para peserta didik lebih menyatu dan tersentuh dengan informasi yang diberikan pendidik, jika menggunakan bahasa daerah. Hasil wawancara kepada peserta didik juga menguatkan bahwa "Kalau ibu guru menjelaskan pelajaran bagus menggunakan bahasa yang mudah dipahami misalnya kalau memberikan contoh menggunakan bahasa sehari-hari seperi bahasa daerah sebagai selingan agar menarik dan tidak mengantuk". Hal ini sesuai dengan pendapat Canale dan Swain (dalam Eva Astriani, 2018) yang mengategorikan kompetensi sosiologis mengunakan bahasa daerah termasuk dalam kompetensi komunikatif.

Sesuai hasil wawancara yang diperoleh dari peserta didik, maka dapat diketahui bahwa peserta didik menginginkan pendidik memberikan materi pelajaran agar diselingi dengan penjelasan yang menggunakan bahasa daerah yang biasanya digunakan dalam kehidupan sehari-hari peserta didik begitupun apabila pendidik memberikan contoh dapat mengambil dari kehidupan sehari-hari para peserta didik sehingga mudah dipahami karena mereka mengalami langsung dalam kehidupan sehari-hari. Hal ini sejalan dengan pendapat Sa'us (2013) yang mengatakan bahwa kesamaan bahasa yang digunakan dapat menciptakan proses komunikasi yang efektif.

Selain hal tersebut dalam memberikan pemahaman kepada peserta didik maka dapat dilakukan dengan berbagai metode baik dalam komunikasi langsung kepada peserta didik maupun komunikasi tidak langsung menggunakan perantara seperti 
buku, gambar dan lain-lain yang dianggap dapat mendukung dalam tercapainya tujuan pelajaran. Ibrahim (2020) mengemukakan bahwa penggunaan media dan alat peraga yang bervariasi merupakan prinsip komunikatif yang harus dipenuhi guru. Penggunaan media dapat membantu guru dalam menyampaikan materi yang ada dan pembelajaran juga menjadi lebih menarik sehingga siswa mudah memahami materi yang dijelaskan (Dahlia, 2019).

Sebagai seorang pendidik maka harus dapat mengetahui kondisi yang terjadi dalam diri peserta didik misalnya ketika peserta didik mengalami kejenuhan pada saat belajar peserta didik dapat melakukan hal-hal yang menarik perhatian peserta didik misalnya dengan humor yang dapat menghilangkan rasa jenuh dan mengatuk terutama pada saat jam terakhir.

Berdasarkan pendapat dari peserta didik di SMP Negeri 5 Palopo dapat diketahui bahwa peserta didik menginginkan ketika pendidik memberikan materi pelajaran sebaiknya diselingi dengan penjelasan yang menggunakan bahasa daerah yang biasanya digunakan dalam kehidupan sehari-hari peserta didik begitu pun apabila pendidik memberikan contoh dapat mengambil dari kehidupan sehari-hari para peserta didik sehingga mudah dipahami karena mereka mengalami langsung dalam kehidupan sehari-hari Kebutuhan bahasa komunikatif dalam pembelajaran yang direkomendasikan, sesuai dengan pendapat Gagne yang mengatakan penganut aliran behavioristik, penggunaan bahasa merupakan asosiasi yang terbentuk melalui proses pengkondisian klasik (clasical conditioning), pengkondisian operan (operant conditioning) dan belajar sosial (social learning) sedangkan menurut kaum empiris yang dipelopori para penganut aliran behavioristik memandang bahwa kemampuan berbahasa merupakan hasil belajar individu dalam interaksinya dengan lingkungan (Asrori, 2015).

\section{E. KESIMPULAN}

Berdasarkan hasil penelitian yang dilakukan dapat disimpulkan bahwa pembelajaran PAI di SMP Negeri 5 Palopo telah menggunakan bahasa komunikatif. Kompetensi komunikatif yang dimiliki guru juga telah memenuhi empat aspek yakni kompetensi gramatikal, kompetensi sosiologis, kompetensi wacana, dan kompetensi strategis. Penggunaan bahasa komunikatif dipengaruhi oleh dua faktor yakni faktor internal dan faktor eksternal. Faktor internal ini berasal dari dalam diri pendidik sedangkan factor eksternal berasal dari peserta didik dan kondisi 
lingkungan. Dalam diri pendidik yakni, kurangnya kemampuan seorang pendidik dalam hal penggunaan bahasa komunikatif, serta kurangnya pemahaman pendidik terhadap peserta didik apakah sudah memahami materi yang disampaikan atau belum. Factor eksternal peserta didik yakni, kurangnya kemampuan peserta didik dalam hal menangkap materi yang disampaikan oleh pendidik, serta minat belajar peserta didik yang menurun. Factor lain yang berpengaruh adalah ketersediaan sarana dan prasana sebagai media yang digunakan guru dalam menyampaikan materi pelajaran. Bahasa komunikatif yang diperlukan dalam proses pembelajaran pendidikan agama Islam yakni bahasa yang mudah dipahami oleh peserta didik, diselingi dengan bahasa daerah, penggunaan media dan alat peraga, serta pemahaman akan kondisi siswa dengan tetap mengacu pada kompetensi komunikatif yang wajib dimiliki guru.

\section{SARAN}

Bahasa komunikatif yang diperlukan dalam proses pembelajaran pendidikan agama Islam peserta didik menginginkan agar pendidik dalam memberikan materi pelajaran sebaiknya diselingi dengan penjelasan yang menggunakan bahasa daerah yang biasanya digunakan dalam kehidupan sehari-hari agar peserta didik dapat memahami contoh yang diberikan oleh pendidik. Dalam implementasi pendidikan agama Islam diperlukan penggunaan bahasa yang komunikatif dengan menyesuaikan situasi dan kondisi pada saat proses pembelajaran.

\section{DAFTAR PUSTAKA}

\section{Sumber dari Jurnal/Penelitian}

Astriani, E. (2014). Kompetensi Komunikatif. PENTAS: Jurnal Ilmiah Pendidikan Bahasa dan Sastra Indonesia, 4(2). 1-7.

Dahlia. (2019). Peningkatan Hasil Belajar IPS Melalui Penggunaan Media Gambar Pada Siswa Kelas III SDN 50 Bulu' Datu Palopo. Pedagogik Journal of Islamic Elementary School, 2(1). 29-40.

Fahmita, L. dkk, (2018). 'Pendekatan Komunikatif Berpengaruh Terhadap Keterampilan Berbicara Mata Pelajaran Bahasa Indonesia Siswa Kelas V SD Gugus VI Kecamatan Gianyar'. Jurnal Mimbar PGSD Universitas Pendidikan Ganesha Jurusan PGSD. 12(1). Tersedia pada: http://id.portalgaruda.org/?ref=browse $\& \bmod =$ viewarticle $\&$ article $=98909$ (diakses: 30 Agustus 2018).

Ibrahim, I. (2020). Pendekatan Ramah, Terbuka dan Komunikatif pada Pembelajaran Matematika di SMP. Jurnal Mercumatika: Jurnal Penelitian Matematika dan Pendidikan Matematika, 4(1). 39-46.

Rustan, E. (2017). Learning Creative Writing Model Based on Neurolinguistic Programming. International Journal of Language Education and Culture Review, 3(2), 
13-29.

https://doi.org/10.21009/IJLECR.032.

02

Saihu. (2019). Komunikasi Pendidik Terhadap Anak Berkebutuhan Khusus di Sekolah Khusus Asy-Syifa Larangan. ANDRAGOGI: Jurnal Pendidikan Islam, 1(3).

Sulistiani, I. (2014). Penggunaan Bahasa Komunikatif dalam Proses Belajar Mengajar. Jurnal Pendidikan Iqra. 2(1).

\section{Sumber dari Buku}

Aminatul, Z. (2015). Membangun Kualitas Pembelajaran Melalui Dimensi Profesionalisme Guru. Bandung: Yrama Widya.

Ardianto, E. (2014). Komunikasi Massa, Bandung: Simbiosa Rekatama Media.

Asrori, M. (2015). Perkembangan Peserta Didik. Yogyakarta: Media Akademi.

Baderiah. (2015). Reorientasi Pendidikan Islam dalam Perspektif Akhlak Era Millenium Ketiga, Palopo: Laskar Perubahan.

Baki, N.A. (2014). Metode Pembelajaran Agama Islam. Yogyakarta: Eja Publisher.

Djamarah, S. B. (2013). Guru dan Anak Didik (dalam Interaksi Edukatif). Banjarmasin: Rineka Cipta.

Fredericks, S. (2013). Invasi Politik dan Budaya Asing. Bogor: Pustaka Thariqul Izzah.

Gunawan, H. (2013). Kurikulum dan Pembelajaran Pendidikan Agama Islam. Bandung: Alfabeta.

Lamin, H. (2011). Penggunaan Bahasa Komunikatif dalam Proses Belajar Mengajar pada SDN Tondok Alla Jaya di Kecamatan Telluwanua Kota Palopo. STAIN Palopo.

Iriantara, Y. (2013). Komunikasi
Pembelajaran (1st ed.). Bandung: Simbiosa Rekatama Media.

Kementerian Agama RI. (2013). Al-Qur'an Al-Karim Tajwid dan Terjemahnya. Surabaya: UD Halim.

Marwiyah, S. (2015). Perencanaan Pembelajaran Pendidikan Agama Islam. Palopo: Aksara Timur.

Mulyasa, E. (2013). Menjadi guru profesional. Bandung: Rosdakarya.

Rahman, M.A. (2008). KesalahanKesalahan Fatal Paling Sering dilakukan Guru dalam Kegiatan Belajar Mengajar. Jakarta: Diva Press.

Rahmawati, A. (2014). Urgensi Komunikatif Antara Orang Tua dan Anak dalam Proses Perkembangan Prilaku Anak Skripsi Program Studi Pendidikan Agama Islam. IAIN Palopo.

Rusman dkk. (2011). Pembelajaran Berbasis Tekhnologi Informasi dan Komunikasi Mengembangkan Profesionalisme Guru. Bandung: Rajawali Pers.

Sa'ud, U.S. (2013). Inovasi Pendidikan. Bandung: Alfabeta.

Sagala, S. (2013). Konsep dan Makna Pembelajaran. Bandung: Alfabeta.

Somad, B. (2009). Ilmu Pendidikan Islam. Jakarta: Rineka Cipta.

Sutirman. (2013). Media dan Model-Model Pembelajaran Inovatif. Yogyakarta: Graha Ilmu.

Syamsu. (2017). Strategi Pembelajaran. Makassar: Nas Media Pustaka.

Tohirin. (2011). Psikologi Pembelajaran Pendidikan Agama Islam (Berbasis Integrasi dan Kompetensi), Jakarta: PT RajaGrafindo Persada.

Usman, B. dan Asnawir. (2002). Media Pembelajaran. Padang: Ciputat Press. 
Yati, D. (2015). Menyelamatkan Bahasa Daerah Melalui Pembelajaran Bahasa Yang Komunikatif. Prosiding Seminar Nasional Bulan Bahasa UNIB 2015. 157-170. 